\title{
PENDIDIKAN KARAKTER PADA SEKOLAH DASAR DI PONDOK PESANTREN DALAM PEMBENTUKAN KEDISIPLINAN, TANGGUNG JAWAB, DAN KEMANDIRIAN SISWA
}

\author{
Miftahul Jannah \\ Dosen, STIQ Amuntai, Kalimantan Selatan, Indonesia
}

\begin{abstract}
An Najah Sekolah Dasar Tahfiz Quran Terpadu (SDTQ-T) Boarding School, Cindai Alus Martapura has more complex instrument than character education process instrument in school or Islamic school because it has uniqueness, where students are schooling and staying in the same environment so that it can form very well and conducive environment for educational and character building process especially in discipline, responsibility and independence.

The objectives of the study are to describe and analyze: (1) Character Education Strategy in building students' discipline, responsibility, and independence in An Najah SDTQ-T Boarding School, Cindai Alus Martapura. (2) Character Education Model in building students' discipline, responsibility, and independence Model in An Najah SDTQ-T Boarding School, Cindai Alus Martapura. (3) Implication of Character Education Model in building students' discipline, responsibility, and independence in An Najah SDTQ-T Boarding School, Cindai Alus Martapura.

This research uses qualitative approach with case study type. The data collection techniques are interview, observation and documentation. The data are analyzed qualitatively with analysis model of Miles and Huberman. The research results show: (1) Character Education Strategy in building students' discipline, responsibility and independence in An Najah SDTQ-T Boarding School, Cindai Alus Martapura are: Emphasizing in awareness, model/example, spontaneous activities, warning, environment conditioned, regular activities, and integrated discipline.(2) Character Education Model in building students' discipline, responsibility and independence in An Najah SDTQ-T Boarding School, Cindai Alus Martapura are habitual, dgiving example, developing discipline, and giving reward and punishment, CTL, conducting education
\end{abstract}

Jurnal Ilmiah AL-MADRASAH, Vol. 2, No. 2, Januari-Juni 2018 
Miftahul Jannah: Pendidikan Karakter pada Sekolah Dasar di Pondok Pesantren Dalam Pembentukan Kedisiplinan, Tanggung Jawab, dan Kemandirian Siswa

with boarding school system. (3) Implication of Character Education Model in building students' discipline, responsibility, and independence are: correct conduct in teaching and learning activities, students' fidelity, students' quality, confidence and achievement, and most of the students achieve minimum score of 70 , the increase of discipline, responsibility, and independence graphic every year in students' score reports.

Keywords:Character Education, Building Discipline, Responsibility, and Independence.

\section{A. Pendahuluan}

Hakikatnya pendidikan merupakan satu pembentukan dan pengembangan kepribadian manusia secara menyeluruh yakni pembentukan dan pengembangan potensi ilmiah yang ada pada diri manusia secara menyeluruh. Oleh karena itu dalam proses pendidikan selain harus menekankan ilmu pengetahuan (kognitif) juga diarahkan pada pengembangan kecerdasan untuk dapat belajar cepat dengan terampil dalam melaksanakan sesuatu (psikomotor) serta diarahkan pada pengembangan sikap mental dan kepribadian untuk terjun di masyarakat (afektif), di dalam Sisdiknas pasal 3 dikatakan bahwa:

Pendidikan Nasional berfungsi mengembangkan kemampuan dan membentuk watak serta peradaban bangsa yang bermartabat dalam rangka mencerdaskan kehidupan bangsa, bertujuan untuk berkembangnya potensi peserta didik agar menjadi manusia yang beriman dan bertaqwa kepada Tuhan Yang Maha Esa, berakhlak mulia, sehat, berilmu, cakap kreatif, mandiri dan menjadi warga Negara yang demokratis serta bertanggungjawab. ${ }^{1}$

SDTQ-T An Najah Pondok Pesantren Cindai Alus Martapura sebagai contoh lembaga pendidikan Islam berbentuk pondok pesantren atau Boarding School, juga mempunyai berbagai misi dalam melahirkan para siswa yang berakhlak mulia diantaranya melalui pendidikan karakter untuk menumbuhkan kedisiplinan, tanggung jawab dan kemandirian, baik kedisiplinan yang diterapkan dalam keseharian siswa di asrama, maupun dalam proses pembelajaran di kelas. Bisa dikatakan bahwa keseharian siswa (24 jam penuh) 2010), h. 3

${ }^{1}$ Republik Indonesia, Undang-Undang SISDIKNAS (Bandung: Fokusmedia, Jurnal Ilmiah AL-MADRASAH, Vol. 2, No. 2, Januari-Juni 2018 
Miftahul Jannah: Pendidikan Karakter pada Sekolah Dasar di Pondok Pesantren Dalam Pembentukan Kedisiplinan, Tanggung Jawab, dan Kemandirian Siswa

tidak lepas dari berbagai pembentukan karakter. Pola pembentukan karakter 24 jam penuh seperti ini tidak akan ditemui kecuali pada lembaga pendidikan Islam yang memiliki konsep sekolah dan asrama sebagaimana yang terdapat dalam lingkungan pondok pesantren.

Berdasarkan pengamatan awal peneliti di SDTQ-T An Najah Pondok Pesantren Cindai Alus Martapura, pendidikan karakter yang diterapkan telah memberikan out put yang luar biasa terhadap kualitas kedisiplinan, tanggung jawab dan kemandirian mereka. Sikap kedisiplinan mereka terlihat ketika tiba waktunya sholat berbondong-bondong menuju masjid. Kondisi ini dapat tercipta diantaranya melalui peraturan tentang kewajiban sholat berjama'ah di masjid yang telah diatur oleh penanggung jawab disiplin keamanan, sikap tanggung jawab siswa terhadap lingkungan juga dapat terlihat melalui lingkungan sekolah dan asrama yang bersih, dimana siswa sangat menjaga kebersihan baik di kamar, asrama, sekolah dan lingkungan asrama secara keseluruhan, tanggung jawab siswa dalam segi hafalan juga penting karena siswa memiliki targettarget yang harus dilakukan berdasarkan peraturan sekolah. Keadaan ini dapat terwujud karena adanya kontroling dari penanggung jawab disiplin kebersihan dan kesehatan, yang menetapkan berbagai peraturan terkait kewajiban memelihara kebersihan, kemudian tanggung jawab dan kemandirian siswa terhadap pribadi dan masyarakat di Sekolah Dasar Tahfiz Quran Terpadu (SDTQ-T) Pondok Pesantren Cindai Alus Martapura dapat dilihat dari sikap mereka yang sangat menghargai waktu, saling membantu, menolong teman yang sakit, dan suka berbagi. Sikap kemandirian mereka juga terlihat dari berbagai aktifitas kegiatan yang mereka lakukan secara sendiri tidak bergantung kepada petugas asrama hal ini juga merupakan buah dari pendidikan yang diterapkan kepada mereka. SDTQ-T An Najah Pondok Pesantren Cindai Alus Martapura merupakan salah satu lembaga pendidikan Islam yang unggul di Kalimantan Selatan, hal ini terbukti dengan banyaknya para siswa yang mengikuti perlombaan berbagai cabang lomba MTQ dan FASI pada tingkat nasional. Oleh karena itu Penelitian ini bertujuan untuk mengkaji Pendidikan 
Miftahul Jannah: Pendidikan Karakter pada Sekolah Dasar di Pondok Pesantren Dalam Pembentukan Kedisiplinan, Tanggung Jawab, dan Kemandirian Siswa

Karakter Pada Sekolah Dasar di Pondok Pesantren dalam Pembentukan Kedisiplinan, Tanggung Jawab dan Kemandirian Siswa.

\section{B. Metode Penelitian}

1. Pendekatan dan Jenis Penelitian

Pendekatan dan Jenis penelitian yang penulis lakukan adalah penelitian kualitatif dengan jenis penelitian studi kasus ${ }^{2}$, yang mana penelitan ini bertujuan untuk membahas tentang model dan strategi serta implikasi pembentukan kedisiplinan, tanggung jawab dan kemandirian yang diterapkan di SDTQ-T An Najah Pondok Pesantren Cindai Alus Martapura.

2. Data dan Sumber Data Penelitian

Karena penelitian ini dikategorikan penelitian kualitatif-empiris, maka data yang digunakan adalah data pokok dan data penunjang. ${ }^{3}$ Data pokok adalah data yang penulis dapatkan secara first hand dari informant, sedangkan data sekunder adalah data yang diperoleh dari buku-buku, data dokumentasi, serta karya-karya ilmiah guna mendukung penelitian ini. ${ }^{4}$

3. Tekhnik Pengumpulan Data

Ada tiga metode teknik pengumpulan data yang digunakan penulis dalam penelitian ini. Pertama, wawancara dalam melakukan wawancara ini peneliti melakukannya dengan dua tehnik, yaitu wawancara terstruktur dan wawancara tak terstruktur. ${ }^{5}$ Kedua macam wawancara tersebut disesuaikan dengan dinamika yang ada pada saat peneliti berada dilapangan, ketika mewawancarai informan yang terdiri dari mudir, kepala sekolah, pengasuhan, ustadz, para siswa. Kedua, observasi. Metode ini digunakan untuk melihat dan mengamati secara langsung keadaan di lapangan agar

\footnotetext{
${ }^{2}$ Lexy. J. Moleong, Metode Penelitian Kualitatif, (Bandung: Remaja Rosda Karya, 2002), h. 3.

${ }^{3}$ Lexy. J. Moleong, Metode Penelitian Kualitatif, (Bandung: PT. Remaja Rosdakarya, 2006), h. 157.

${ }^{4}$ Robert C. Bogdan dan Sari Nop Biklen, Qualitative Research in Education an Introduction to Theory and Method (London: Allyn and Bacon, 1998), h. 54.

${ }^{5}$ Lexy J.Moleong, Metodologi..., h. 186.
}

Jurnal Ilmiah AL-MADRASAH, Vol. 2, No. 2, Januari-Juni 2018 
Miftahul Jannah: Pendidikan Karakter pada Sekolah Dasar di Pondok Pesantren Dalam Pembentukan Kedisiplinan, Tanggung Jawab, dan Kemandirian Siswa

peneliti memperoleh gambaran yang lebih luas tentang permasalahan yang diteliti $^{6}$, yaitu berbaur dengan warga sekolah untuk memahami langsung pendidikan karakter di pondok pesantren dalam pembentukan kedisiplinan, tanggung jawab dan kemandirian siswa yang diteliti. Ketiga, dokumentasi, penulis juga mengumpulkan data dengan cara dokumentasi baik dari bukubuku, arsip dokumen dari sekolah supaya data yang diperoleh lebih akurat dan sistematis.

\section{Tekhnik Analisis Data}

Setelah pengumpulan data selesai langkah berikutnya menganalisis data peneliti menggunakan tehnik analisis data Miles dan Huberman, yang dilakukan melalui tiga langkah: (1) Reduksi data, dengan cara proses pemilihan, pemusatan perhatian, pengabstraksian dan pentransformasian data kasar dari lapangan. Fungsinya untuk menajamkan, menggolongkan, mengarahkan, membuang yang tidak perlu, dan mengorganisasi sehingga interpretasi bisa ditarik kesimpulan. (2) Penyajian data, dengan cara Sekumpulan informasi tersusun yang memberi kemungkinan untuk menarik kesimpulan dan pengambilan tindakan. Bentuk penyajiannya antara lain berupa teks naratif, matriks, grafik, jaringan, dan bagan. (3) Penarikan kesimpulan (verifikasi), dengan cara memeriksa data temuan yang dinilai absah dan kemudian menarik kesimpulan sehingga dapat memperoleh hasil analisis yang sesuai. ${ }^{7}$

5. Pengecekan Keabsahan Data

Pengecekan keabsahan data, peneliti menggunakan teknik trianggulasi. Triangulasi adalah teknik pemeriksaan keabsahan data yang memanfaatkan sesuatu yang lain di luar data itu untuk keperluan pengecekan atau sebagai pembanding terhadap data itu. Teknik trianggulasi

\footnotetext{
${ }^{6}$ Basrowi dan Suwandi, Memahami Penelitian Kualitatif (Jakarta: Rineka Cipta, 2008), h. 93-94.

${ }^{7}$ Basrowi dan Suwandi, Memahami..., h. 209-210.
}

Jurnal Ilmiah AL-MADRASAH, Vol. 2, No. 2, Januari-Juni 2018 
Miftahul Jannah: Pendidikan Karakter pada Sekolah Dasar di Pondok Pesantren Dalam Pembentukan Kedisiplinan, Tanggung Jawab, dan Kemandirian Siswa

yang digunakan penulis ada empat, yaitu Triangulasi pengumpulan data, Triangulasi teori, Triangulasi dengan sumber dan Triangulasi metode. ${ }^{8}$

\section{Kerangka Berpikir}

Kerangka berfikir yang digunakan dalam penelitian ini dimulai dari mendiskripsikan pendidikan karakter di pondok pesantren dalam pembentukan kedisiplinan, tanggung jawab dan kemandirian siswa di SDTQ-T An Najah Pondok Pesantren Cindai Alus Martapura yang didapat dari hasil wawancara, observasi dan dokumentasi. Data temuan penelitian tersebut kemudian dianalisis dengan berbagai macam teori tentang pendidikan karakter, model, strategi pendidikan karakter dalam pembentukan kedisiplinan, tanggung jawab dna kemandirian untuk menguak implikasi dari pendidikan karakter dalam pembentukan kedisiplinan, tanggung jawab dan kemandirian siswa.

\section{Pembahasan}

1. Model Pendidikan Karakter dalam Pembentukan Kedisiplinan, Tanggung jawab dan Kemandirian Siswa.

Secara kaffah, model dinamai suatu objek atau konsep yang digunakan untuk mempresentasikan sesuatu hal, atau sesuatu yang nyata dan dikonversi untuk sebuah bentuk yang lebih konprehensif. ${ }^{9}$ Pendapat lain mengatakan model diartikan sebagai kerangka konseptual yang dipergunakan sebagai pedoman atau acuan dalam melakukan suatu kegiatan. ${ }^{10}$ Model juga merupakan implikasi dari suatu sistem yang menggambarkan keadaan yang sebenarnya. Dalam arti luas, model merupakan pengembangan sebagian dari kenyatan pada suatu bidang ilmu pengetahuan. Model adalah pola dari

\footnotetext{
${ }^{8}$ Benjamin. F. Crabtee \& William L. Miller. Doing Qualitative Research Methods for Primary Care (New Delhi: Sage Publications, 1998), h. 5.

${ }^{9}$ Anissatul MUFAROKAH, Strategi dan Model-Model Pembinaan (STAIN Tulungagung: Press, 2013), h. 66.

${ }^{10}$ Muhaimin, Paradigma Pendidikan Islam: Upaya Mengefektifkan Pendidikan Agama Islam di Sekolah (Bandung: PT Remaja Rosdakarya, 2008), h. 223
}

Jurnal Ilmiah AL-MADRASAH, Vol. 2, No. 2, Januari-Juni 2018 
Miftahul Jannah: Pendidikan Karakter pada Sekolah Dasar di Pondok Pesantren Dalam Pembentukan Kedisiplinan, Tanggung Jawab, dan Kemandirian Siswa

sesuatu yang akan dibuat atau dihasilkan. Dari beberapa pengertian dapat disimpulkan bahwa model merupakan sebuah konsep, bentuk atau pola yang digunakan untuk menggambarkan sesuatu yang dijadikan titik tolak dari sebuah proses.

Mengenai model pendidikan karakter dunia Barat khususnya di Amerika Serikat melaksanakan pendidikan karakter dengan menggunakan pendekatan holistik (menyeluruh). Artinya seluruh warga sekolah mulai dari guru, karyawan dan para murid harus terlibat dan bertanggungjawab terhadap pelaksanaan pendidikan karakter. Hal yang paling penting disini adalah bahwa pengembangan karakter harus terintegrasi kedalam setiap asfek kehidupan sekolah. Pendekatan semacam ini disebut juga reformasi sekolah menyeluruh dan menjadi tanggung jawab bagi para pendidik dan orang tua terhadap perkembangan siswa saat berada di ruang lingkup sekolah maupun saat berada di rumah.

Berikut beberapa gambaran bagaimana penerapan model holistik dalam pendidikan karakter:

a. Segala sesuatu yang ada di sekolah terorganisasikan diseputar hubungan antara siswa dan guru beserta staf dan komunitas disekitarnya.

b. Sekolah merupakan komunitas yang peduli (Caring Comunity) dimana terdapat ikatan yang kuat yang menghubungkan antara siswa dan guru beserta staf sekolah.

c. Kooperasi dan kolaborasi antara siswa lebih ditekankan pengembangannya daripada kompetensi.

d. Nilai-nilai seperti fairness (kejujuran) dan saling menghormati adalah bagian dari pembelajaran setiap hari, baik didalam maupun diluar kelas.

e. Para siswa diberikan keluasan untuk mempraktikkan perilaku moral melalui kegiatan pembelajaran untuk melayani (service learning).

Jurnal Ilmiah AL-MADRASAH, Vol. 2, No. 2, Januari-Juni 2018 
Miftahul Jannah: Pendidikan Karakter pada Sekolah Dasar di Pondok Pesantren Dalam Pembentukan Kedisiplinan, Tanggung Jawab, dan Kemandirian Siswa

f. Disiplin kelas dan pengelolaan kelas dipusatkan pada pemecahan masalah daripada dipusatkan pada penghargaan dan hukuman.

g. Model lama berupa pendekatan berbasis guru yang otoriter tidak pernah lagi diterapkan di luar kelas, tetapi lebih dikembangkan melalui suasana kelas yang demokratis dimana para guru dan siswa melaksanakan semacam pertemuan kelas untuk membangun kebersamaan, menegakkan norma-norma yang disepakati bersama, serta memecahkan masalah bersama-sama. ${ }^{11}$

Selanjutnya Mulyasa menawarkan beberapa model pendidikan karakter yang dapat diaplikasikan dalam suatu pendidikan. Seperti melakukan kebiasaan, keteladanan, pemberian reward and punishment serta melaksanakan pembelajaran dengan pendekatan $C T L .^{12}$

a. Pembiasaan

Pembiasaan adalah sesuatu yang sengaja dilakukan secara berulang-ulang agar sesuatu itu dapat menjadi kebiasaan. Dalam model pembiasaan, manusia ditempatkan sesuatu yang istimewa dapat menghemat kekuatan, karena akan menjadi kebiasaan yang melekat dan spontan dalam setiap pekerjaan dan aktifitas lainnya, dalam bidang psikologi pendidikan, metode pembiasaan dikenal dengan istilah operan conditioning, yaitu mengajarkan peserta didik untuk membiasakn perilaku terpuji, disiplin, tanggung jawab, mandiri, giat belajar, bekerja keras, ikhlas dan jujur atas setiap tugas yang diberikan b. Keteladanan

Keteladanan guru sangat besar pengaruhnya terhadap pertumbuhan dan perkembangan pribadi para peserta didik. Oleh karena itu dalam menefektifkan dan mensukseskan pendidikan karakter di sekolah, setiap guru dituntut untuk memiliki kompetensi kepribadian

\footnotetext{
${ }^{11}$ Muchlas Samani dan Hariyanto, Konsep dan Model Pendidikan Karakter (Bandung: PT Remaja Rosdakarya, 2014), h. 139-140

${ }^{12}$ E. Mulyasa, Management Pendidikan Karakter (Jakarta: PT Bumi Aksara, 2011), h. 165-190
}

Jurnal Ilmiah AL-MADRASAH, Vol. 2, No. 2, Januari-Juni 2018 
Miftahul Jannah: Pendidikan Karakter pada Sekolah Dasar di Pondok Pesantren Dalam Pembentukan Kedisiplinan, Tanggung Jawab, dan Kemandirian Siswa

yang memadai. Dalam keteladanan ini pula guru harus berani tampil berbeda dengan penampilan orang yang bukan profesi sebagai guru. Sebab penampilan guru dalam berpakaian, bertutur kata dan berperilaku dapat membuat peserta didik senang belajar dan betah dikelas, selain dari itu peserta didik juga akan tampil sebagai pribadi yang baik sebagaimana yang diteladankan oleh gurunya.

c. Pembinaan disiplin

Dalam rangka mensukseskan pendidikan karakter, guru juga harus dapat menumbuhkan disiplin peserta didik, terutama disiplin diri (self dicipline). Disamping itu, guru harus mampu membantu peserta didik mengembangkan pola perilakunya, meningkatkan standar perilakunya dan melaksanakan aturan sebagai alat menegakkan disiplin.

d. Pemberian Hadiah dan Hukuman

Apresiasi pemberian hadiah atau penghargaan sangat dibutuhkan sebagai stimulus bagi perkembangan peserta didik ke arah yang lebih baik. Penerapan hukuman (phunisment) juga sangat dibutuhkan sebagai sebuah peringatan dan ketaatan pada peraturan yang telah disepakati bersama. Dalam persfektif pendidikan pemberian hadiah dan hukuman haruslah diberikan dengan prinsip kepantasan dan kemanusiaan. Terutama dalam hal hukuman, sangsi yang diberikan haruslah bersifat konstruktif dan tetap penuh dengan nilai-nilai pendidikan dan jauh dari hukuman yang sifatnya membunuh karakter peserta didik.

Hukuman memegang peranan penting dalam pendidikan karakter. Akan tetapi hukuman adalah alternatif terakhir apabila semua cara telah dilaksanakan namun anak tidak jera. Dimana anak telah diberikan penjelasan tentang peraturan kedisiplinan yang harus dilaksanakan, kemudian ia tetap melanggar dan telah diberi peringatan, maka hukumanlah yang menjadi alternatif selanjutnya. 
Miftahul Jannah: Pendidikan Karakter pada Sekolah Dasar di Pondok Pesantren Dalam Pembentukan Kedisiplinan, Tanggung Jawab, dan Kemandirian Siswa

Hukuman mempunyai tiga fungsi penting yang berperan dalam perkembangan moral anak, yaitu:

1) Menghalangi, hukuman menghalangi pengulangan tindakan yang tidak diinginkan oleh masyarakat. Bila anak menyadari bahwa tindakan tertentu akan dihukum, mereka biasanya urung melakukan tindakan tersebut karena teringat akan hukuman yang dirasakannya di waktu lampau akibat tindakan tersebut.

2) Mendidik, sebelum anak mengerti peraturan mereka dapat belajar bahwa tindakan tertentu benar dan yang lain salah dengan mendapat hukuman karena melakukan tindakan yang salah dan tidak menerima hukuman bila mereka melakukan tindakan yang diperbolehkan. Aspek edukatif lain dari hukuman yang sering kurang diperhatikan adalah mengajar anak membedakan besar kecilnya kesalahan yang diperbuat mereka.

3) Memberi motivasi untuk menghindari perilaku yang tidak diterima di masyarakat. Pengetahuan tentang akibat-akibat tindakan yang salah perlu sebagai motivasi untuk menghindari kesalahan tersebut.

\section{e. Contextual Teaching and Learning (CTL)}

Model Pembelajaran Konstektual atau Contextual Teaching and Learning), dapat dijadikan model pembelajaran untuk pendidikan karakter karena dalam pelaksanaannya lebih menekankan keterkaitan antara materi pembelajaran dengan kehidupan nyata, sehingga peserta didik mampu menghubungkan dan menerapkan kompetensi hasil belajar dalam kehidupan sehari-hari.

Selain itu Suyanto menawarkan beberapa desain agar pendidikan karakter dapat berjalan dengan baik, seperti (1) desain berbasis kelas, yang berbasis pada relasi guru sebagai pendidik dan siswa sebagai pembelajar (2) desain berbasis kultur sekolah yang mampu membentuk karakter peserta didik dengan bantuan pranata sosial agar nilai tertentu 
Miftahul Jannah: Pendidikan Karakter pada Sekolah Dasar di Pondok Pesantren Dalam Pembentukan Kedisiplinan, Tanggung Jawab, dan Kemandirian Siswa

terbentuk dan terbatinkan dalam diri siswa (3) desain berbasis komunitas. $^{13}$

2. Strategi Pendidikan Karakter dalam Pembentukan Kedisiplinan, Tanggung jawab dan Kemandirian Siswa.

Menurut kamus besar Bahasa Indonesia, "strategi adalah rencana yang cermat mengenai kegiatan untuk mencapai sasaran khusus". ${ }^{14}$ Strategi juga bisa diartikan sebagai rangkaian keputusan dan tindakan untuk mencapai suatu maksud dalam pencapaian tujuan. Dalam konteks pendidikan strategi adalah seni dan ilmu untuk membawakan pengajaran di kelas sedemikian rupa, sehingga tujuan yang telah ditetapkan dapat tercapai secara efektif dan efisien. ${ }^{15}$ Definisi senada strategi adalah cara untuk mencapai tujuan jangka panjang atau proses penentuan rencana para pemimpin puncak.

Strategi Pendidikan dalam Membentuk kedisiplinan, tanggung jawab dan kemandirian pada siswa atau santri adalah sebagai berikut:

a. Strategi di tingkat kementrian pendidikan dasar

Pendekatan yang digunakan Kementrian Pendidikan Nasional dalam pengembangan Pendidikan Karakter, yaitu: pertama melalui stream top down, kedua melalui stream bottom up, ketiga melalui stream revitalisasi program.

1) stream top down

Dalam stream ini pemerintah menggunakan 5 strategi yang dilakukan secara koheran, yaitu sosialisasi, pengembangan regulasi, pengembangan kapasitas, implementasi dan kerjasama, monitoring dan evaluasi. ${ }^{16}$

\footnotetext{
${ }^{13}$ Suyanto, Pendidikan Karakter; Teori dan Aplikasi, (Jakarta: Aneka Cipta, 2010), h. 70

${ }^{14}$ Tim Penyusun Kamus Pusat Pembinaan dan Pengembangan Bahasa Dep. Pendidikan Kebudayaan, Kamus Besar Bahasa Indonesia (Jakarta: Balai Pustaka, 1998), h. 589

${ }^{15}$ W. Gulo, Strategi Belajar Mengajar (Jakarta: PT Raja Grafindo, 2005), h. 2

${ }^{16}$ Pedoman Pelaksanaan Pendidikan Karakter, (Jakarta: Puskurbuk, 2011), h. 6
}

Jurnal Ilmiah AL-MADRASAH, Vol. 2, No. 2, Januari-Juni 2018 
Miftahul Jannah: Pendidikan Karakter pada Sekolah Dasar di Pondok Pesantren Dalam Pembentukan Kedisiplinan, Tanggung Jawab, dan Kemandirian Siswa

\section{2) stream bottom up}

Dalam stream ini diharapkan dari inisiatif dari satuan pendidikan. Pemerintah memberikan bantuan tekhnis kepada sekolah-sekolah yang telah mengembangkan dan melaksanakan pendidikan karakter sesuai dengan ciri khas dilingkungan sekolah tersebut.

3) stream revitalisasi program

Merevitalisasi kembali program-program kegiatan pendidikan karakter dimana pada umumnya banyak terdapat kegiatan ekstrakurikuler yang sudah ada dan setara dengan nilainilai karakter.

b. Stategi dalam bentuk Pengintegrasian dalam kegiatan sehari-hari ${ }^{17}$

1) Keteladanan/Contoh

Kegiatan pemberian contoh/teladan dalam hal ini guru mempunyai peran vital dalam proses keteladanan. Sikap dan perilaku guru mempunyai implikasi yang luar biasa terhadap muridmuridnya . kepribadian guru mempunyai pengaruh langsung dan komulatif terhadap perilaku siswa. Perilaku guru dalam mengajar secara langsung atau tidak langsung mempunyai pengaruh terhadap motivasi belajar siswa, baik yang sifatnya positif maupun negatif.

2) Kegiatan spontan

Kegiatan yang dilaksanakan secara spontan pada saat itu juga. Kegiatan ini biasanya dilaksanakan pada saat guru mengetahui sikap/tingkah laku siswa yang kurang baik, seperti meminta sesuatu dengan berteriak atau mencoret dinding.

\footnotetext{
${ }^{17}$ Masnur, Muslich, Pendidikan Karakter Menjawab Tantangan Krisis Multidemensional, (Jakarta, PT Bumi Aksara, 2011), h. 177
}

Jurnal Ilmiah AL-MADRASAH, Vol. 2, No. 2, Januari-Juni 2018 
Miftahul Jannah: Pendidikan Karakter pada Sekolah Dasar di Pondok Pesantren Dalam Pembentukan Kedisiplinan, Tanggung Jawab, dan Kemandirian Siswa

\section{3) Teguran}

Guru perlu menegur siswa yang berperilaku buruk dan mengingatkannya agar mengamalkan nilai-nilai baik sehingga dapat membantu siswa mengubah tingkah laku mereka.

4) Pengkondisian lingkungan

Suasana di sekolah dikondisikan sedemikian rupa dengan penyediaan sarana dan prasarana secara baik. Contoh penyediaan tempat sampah, jam dinding, slogan-slogan mengenai karakter kedisiplinan, tanggung jawab, mandiri atau budi pekerti lainnya yang mudah dibaca peserta didik, aturan tata tertib yang ditempelkan pada tempat yang strategis sehingga peserta didik mudah membacanya.

\section{5) Kegiatan rutin}

Kegiatan rutin merupakan kegiatan yang dilakukan siswa secara terus-menerus dan konsisten setiap saat. Contoh kegiatan ini adalah berbaris masuk ruang kelas, berdoa sebelum dan sesudah kegiatan, mengucapkan salam bila bertemu dengan orang lain, membersihkan kelas dan belajar.

c. Pengintegrasian dalam kegiatan yang diprogramkan.

Strategi ini dilakukan setelah terlebih dahulu guru membuat perencanaan atas nilai-nilai yang akan diintegrasikan dalam kegiatan tertentu. Hal ini dilakukan jika guru menganggap perlu memberikan pemahaman atau prinsip-prinsip moral yang diperlukan.

Tabel 2.2 Nilai karakter yang Diintegrasikan dalam kegiatan

\begin{tabular}{|l|l|}
\hline Kegiatan yang diintegrasikan & \multicolumn{1}{|c|}{ Sasaran kegiatan } \\
\hline Kedisiplinan & $\begin{array}{l}\text { Dilakukan pada saat upacara, } \\
\text { melakukan kegiatan tepat waktu }\end{array}$ \\
\hline Tanggung jawab & $\begin{array}{l}\text { Menyelesaikan tugas, melaksanakan } \\
\text { tugas piket }\end{array}$ \\
\hline Kemandirian & $\begin{array}{l}\text { Melaksanakan shalat dhuha secara } \\
\text { sendiri di sekolah, mengerjakan tugas } \\
\text { sekolah dengan baik secara sendiri }\end{array}$ \\
\hline
\end{tabular}

Jurnal Ilmiah AL-MADRASAH, Vol. 2, No. 2, Januari-Juni 2018 
Miftahul Jannah: Pendidikan Karakter pada Sekolah Dasar di Pondok Pesantren Dalam Pembentukan Kedisiplinan, Tanggung Jawab, dan Kemandirian Siswa

d. Melalui manajemen kelas

Praksis pendidikan karakter di dalam kelas menuntut setiap guru untuk memiliki cara-cara untuk bertindak sebagai berikut:

1) Bertindak sebagai pengasuh, teladan dan pembimbing

2) Menciptakan sebuah komunitas moral

3) Menegakkan disiplin moral melalui pelaksanaan kesepakatan yang telah ditentukan sebagai aturan main bersama

4) Menciptakan sebuah lingkungan kelas yang demokratis, dengan cara melibatkan para siswa dalam mengambil keputusan atau bertanggung jawab bagi terbentuknya kelas sebagai tempat belajar yang menyenangkan.

5) Mengajarkan nilai-nilai kedispilinan, tanggung jawab dan kemandirian melalui kurikulum dengan cara menggali isi materi pembelajaran dari mata pelajaran yang sangat kaya dengan nilainilai moral.

6) Mempergunakan metode pembelajaran melalui kerja sama agar siswa semakin mampu mengembangkan kemampuan mereka dalam memberikan apresiasi atas pendapat orang lain, berani memiliki pendapat sendiri, dan mao bekerja sama dengan orang lain.

7) Melatih siswa unutk memecahkan konflik yang muncul secara adil dan damai. ${ }^{18}$

e. Strategi Pendidikan dalam Membentuk kedisiplinan, tanggung jawab dan kemandirian pada siswa atau santri adalah sebagai berikut: ${ }^{19}$

1) Menumbuhkan Konsep Diri (Self Concept)

Strategi ini menekankan bahwa konsep-konsep diri siswa atau santri merupakan faktor penting dari perilaku, untuk

${ }^{18}$ Doni. A. Koesoema, Pendidikan Karakter Strategi Mendidik Anak pada Zaman Global (Jakarta: Grasindo, 2007), h. 233

${ }^{19}$ Agus Wibowo, Pendidikan karakter, Strategi Membangun Karakter Bangsa (Yogyakarta: Pustaka Pelajar, 2012), h. 35.

Jurnal Ilmiah AL-MADRASAH, Vol. 2, No. 2, Januari-Juni 2018 
Miftahul Jannah: Pendidikan Karakter pada Sekolah Dasar di Pondok Pesantren Dalam Pembentukan Kedisiplinan, Tanggung Jawab, dan Kemandirian Siswa

menumbuhkan konsep diri, guru disarankan bersikap empati, menerima hangat, terbuka sehingga siswa atau santri dapat mengeksplorasikan pikiran dan perasannya dalam memecahkan masalah.

2) Memiliki Keterampilan Berkomunikasi

Guru harus memiliki keterampilan komunikasi yang efektif agar mampu menerima semua perasaan, dan mendorong timbulnya kepatuhan peserta didik.

3) Memberikan Konsekuensi-Konsekuensi Logis dan Alami (Natural And Local Consequences)

Perilaku-perilaku yang salah terjadi karena siswa atau santri telah mengembangkan kepercayaan yang salah terhadap dirinya. Hal ini mendorong munculnya perilaku-perilaku salah. Untuk itu, guru disarankan:

a) Menunjukkan secara tepat tujuan perilaku salah, sehingga membantu peserta didik dalam mengatasi perilakunya.

b) Memanfaatkan sebab-akibat logis dan alami dari perilaku yang salah.

4) Klarifikasi Nilai (Value Clarification)

Strategi ini dilakukan untuk membantu siswa atau santri dalam menjawab pertanyaan sendiri tentang nilai-nilai dan membentuk nilainya sendiri.

5) Analisis Transaksional (Transactional Analysis)

Disarankan agar guru belajar sebagai orang dewasa, terutama apabila berhadapan dengan peserta didik yang menghadapi masalah.

6) Terapi Realitas (Reality Therapy)

Sekolah harus berupaya menguranig kegagalan dan meningkatkan keterlibatan, dalam hal ini guru harus bersikap positif dan bertanggung jawab.

Jurnal Ilmiah AL-MADRASAH, Vol. 2, No. 2, Januari-Juni 2018 
Miftahul Jannah: Pendidikan Karakter pada Sekolah Dasar di Pondok Pesantren Dalam Pembentukan Kedisiplinan, Tanggung Jawab, dan Kemandirian Siswa

7) Disiplin yang Terintegrasi (Assertive Disipline)

Metode ini menekankan pengendalian penuh oleh guru untuk mengembangkan dan mempertahankan peraturan. Prinsipprinsip ini modifikasi perilaku yang sistematik diimplementasikan di kelas, termasuk pemanfaatan papan tulis untuk menuliskan namanama peserta didik atau santri yang menyimpang dari peraturan kedisiplinan

8) Modifikasi Perilaku (Behavior Modification)

Perilaku salah disebakan oleh lingkungan, sebagai tindakan remediasi. Sehubungan dengan hal tersebut, dalam pembelajaran perlu diciptakan lingkungan yang kondusif.

9) Melakukan Tantangan Kedisiplinan (Dare to Discipline)

Guru diharapkan cekatan, sangat terorganisasi, dan dalam pengendalian yang tegas. Pendekatan ini mengasumsikan bahwa peserta didik atau santri akan menghadapi berbagai keterbatasan pada hari-hari pertama di sekolah, dan guru perlu membiarkan mereka untuk mengetahu siapa yang berada pada posisi pemimpin. ${ }^{20}$

f. Strategi umum pendidikan karakter yang diterapkan oleh NegaraNegara Barat diantaranya:

1) Cheerleading

Strategi pemanduan melaui berbagai macam poster-poster atau spanduk, buletin, dan lain sebagainya.

2) Praise-and-Reward

Strategi ini menggunakan pujian dan hadiah yaitu dengan cara memberikan pujian dan sesuatu yang bermanfaat kepada para siswa yang berprestasi bertujuan untuk menjadikan siswa lebih berprestasi lagi.

\section{2}

${ }^{20}$ Mulyasa, Manajemen Pendidikan Karakter (Jakarta: Bumi Aksara, 2012), h.

Jurnal Ilmiah AL-MADRASAH, Vol. 2, No. 2, Januari-Juni 2018 
Miftahul Jannah: Pendidikan Karakter pada Sekolah Dasar di Pondok Pesantren Dalam Pembentukan Kedisiplinan, Tanggung Jawab, dan Kemandirian Siswa

\section{3) Define-and Drill}

Strategi ini meminta siswa mengingat berbagai hak kebaikan dan mendefinisikannya menggunakan tahaf perkembangan asfek kognitifnya.

\section{4) Forced-Formality}

Strategi ini menggunakan tahap pembiasaan dalam kegiatan sehari-hari dan kebiasaan tersebut dilakukan secara rutin yang bernilai kebaikan moral.

\section{5) Traits Of The Month}

Strategi ini pada umumnya menyerupai strategi cheerleading akan tetapi menggunakan sesuatu yang terkait pendidikan karakter, seperti berbagai pelatihan, kegiatan ekstrakurikuler, sambutan kepala sekolah dan lain sebagainya.

6) Guru Pembimbing

Strategi ini banyak digunakan negara lain. Strategi ini sangat bergantung dari pribadi guru pembimbing karena strategi ini menuntut guru Bimbingan Konseling berperan aktif serta mempunyai sifat sebagai panutan terutama untuk anak didiknya. ${ }^{21}$

\section{E. Implikasi Pendidikan Karakter di pesantren dalam Membentukan Kedisiplinan Tanggung jawab dan Kemandirian.}

Implikasi dari Model Pendidikan Karakter di pesantren dalam Membentukan Kedisiplinan Tanggung jawab dan Kemandirian adalah:

a. Implikasi Pada Perilaku

Anak yang didik dengan kedisiplinan, tanggung jawab dan kemandrian yang keras atau otoriter akan sangat patuh pada orang dewasa, sangat mandiri dan bertanggung jawab pada orang dewasa namun sangat

\footnotetext{
${ }^{21}$ Muchlas Samani dan Hariyanto, Pendidikan Karakter (Bandung: PT Remaja Rosdakarya, 2011), h. 144-145
}

Jurnal Ilmiah AL-MADRASAH, Vol. 2, No. 2, Januari-Juni 2018 
Miftahul Jannah: Pendidikan Karakter pada Sekolah Dasar di Pondok Pesantren Dalam Pembentukan Kedisiplinan, Tanggung Jawab, dan Kemandirian Siswa

agresif dengan teman sebayanya. Adapun anak yang didik dengan kedisiplinan, tanggung jawab dan kemandrian yang sangat lemah maka dia akan cenderung mementingkan dirinya sendiri, tidak menghiraukan hak orang lain, agresif dan jiwa sosial rendah. Anak yang didik dengan kedisiplinan, tanggung jawab dan kemandirian model pembinaan disiplin demokratis, keteladanan, pembiasan dan CTL akan lebih mampu belajar dalam mengendalikan perilaku yang salah dan mempertimbangkan hak-hak orang lain. ${ }^{22}$ Dengan adanya karakter atau akhlak maka seseorang ata anak didik dapat memperkirakan reaksi-reaksi dirinya terhadap berbagai fenomena yang muncul dalam diri ataupun hubungannya dengan orang lain, dalam berbagai keadaan serta bagaimana mengendalikannya. ${ }^{23}$

b. Pengaruh Pada Sikap

Anak yang dibesarkan dengan cara model pembinaan disiplin dengan strategi yang otoriter maupun yang permisif dan model pemberiaan hukuman cenderung membenci orang yang berkuasa karena merasa mendapat perlakuan yang tidak adil, sedangkan anak yang dibesarkan dengan pembinaan disiplin, kemandirian dan tanggung jawab yang lemah akan merasa bahwa tidak semua orang dewasa akan menerima perilakunya. Adapun anak yang dibessrkan dengan kedisiplinan, tanggung jawab dan kemandirian model pembinaan disiplin demokratis, keteladanan, pembiasan dan $C T L$ akan menyebabkan kemarahan sementara namun bukan sebuah kebencian.

c. Pengaruh Pada Kepribadian

Semakin banyak pemberian hukuman fisik kepada anak maka semakin keras kepribadiannya. Namun saat anak dibesarkan dengan kedisiplinan, tanggung jawab dan kemandirian yang lemah maka jiwa sosialnya akan lemah. Sementara anak yang dibesarkan dengan kedisiplinan,

${ }^{22}$ Tulus Ta'u, Peran Kedisiplinan Pada Perilaku....,h. 91

${ }^{23}$ Agus Setiawan, Prinsip Pendidikan Karakter dalam Islam (Studi Komparasi Pemikiran al-Ghazali dan Burhanuddin al-Zarnuji), Dinamika Ilmu, 14 (1), 2014, h. 6 
Miftahul Jannah: Pendidikan Karakter pada Sekolah Dasar di Pondok Pesantren Dalam Pembentukan Kedisiplinan, Tanggung Jawab, dan Kemandirian Siswa

tanggung jawab dan kemandirian dengan menerapkan model pembinaan disiplin demokratis, keteladanan, pembiasan dan CTL, maka anak akan mampu memiliki penyesuaian pribadi dan penyesuaian sosial yang baik.

\section{F. Penutup}

1. Simpulan

Berdasarkan temuan penelitian dalam uraian dan analisis dalam penelitian ini dapat diambil kesimpulan model yang dilakukan Model Pendidikan Karakter dalam Pembentukan Kedisiplinan, Tanggung Jawab dan Kemandirian siswa di SDTQ-T An Najah Pondok Pesantren Cindai Alus Martapura ada 6 model yang dilaksanakan di SDTQ-T An Najah Pondok Pesantren Cindai Alus Martapura, Kalimantan Selatan dalam pembentukan Kedisiplinan, Tanggung Jawab dan Kemandirian siswa yaitu: (1)Pembiasaan ialah sesuatu hal yang sering dilakukan secara berulangulang dalam membentuk kedisiplinan, tanggung jawab dan kemandirian di SDTQ-T An Najah Pondok Pesantren Cindai Alus Martapura, (2) Memberikan keteladanan dalam mendidik dan dimulai keteladanan oleh para guru baik di sekolah maupun di asrama, (3) Pembinaan dengan penegakan disiplin, (4) Pemberian hadiah dan hukuman, (5) Pembelajaran dengan model Contextual Teaching and Learning (CTL), (6) Melaksanakn pendidikan dengan sistem pondok pesantren atau boarding school. Sedangkan Strategi pendidikan karakter dalam pembentukan kedisiplinan, tanggung jawab dan kemandirian siswa di SDTQ-T An Najah Pondok Pesantren Cindai Alus Martapura ialah: (1) Menekankan pada kesadaran (al-wa'yu al-nafsi) akan pentingnya hidup berdisiplin, tanggung jawab dan mandiri dan tindakan-tindakan pencegahan dan menghilangkan sanksi ('iqâb) fisik, (2) Melakukan teguran secara spontan dan juga keteladanan secara langsung kepada siswa, (3) Keteladanan/Contoh, (4) Kegiatan spontan, ialah Kegiatan yang dilaksanakan secara spontan pada saat itu juga, (5) Teguran, (6) Pengkondisian lingkungan, (7) Kegiatan rutin, (8)

Jurnal Ilmiah AL-MADRASAH, Vol. 2, No. 2, Januari-Juni 2018 
Miftahul Jannah: Pendidikan Karakter pada Sekolah Dasar di Pondok Pesantren Dalam Pembentukan Kedisiplinan, Tanggung Jawab, dan Kemandirian Siswa

Disiplin yang terintegrasi (assertive disipline) ialah mengembangkan dan mempertahankan peraturan, dan Implikasi Pendidikan Karakterdalam pembentukan kedisiplinan, tanggung jawab dan kemandirian siswa di SDTQ-T An Najah Pondok Pesantren Cindai Alus Martapura penulis membagi dari tiga asfek Kegiatan Belajar Mengajar (KBM), kegiatan Ekstrakurikuler dan aktivitas-aktivitas religius yaitu: (1) Terciptanya ketertiban dalam kegiatan belajar mengajar, baik di sekolah maupun di asrama. (2) Mencetak para siswa yang berkualitas dan percaya diri serta berprestasi, (3) Dengan kedisiplinan, tanggung jawab dan kemandirian yang dimilki siswa maka para siswa di SDTQ-T An Najah hampir semua siswa berhasil mencapai KKM 70 (4) Adanya peningkatan grafik setiap tahun diraport siswa tentang acuan penilaian karakter terutama kedisiplinan, tanggung jawab dan kemandirian (5) Dalam hal Kedisiplinan, Tanggung Jawab dan Kemandirian para siswa mentaati dan menjalankan peraturan Kedisiplinan, Tanggung jawab dan Kemandirian, kegiatan ekstrakurikuler banyak para siswa yang menjadi juara tartil, juara Tahfizh dan sudah 3 kali juara berturut-turut dalam ekskul pramuka tingkat penggalang kabupaten Banjar dan aktivitas-aktivitas religius seperti Para siswa semakin rajin dan giat dalam melakukan kegiatan-kegiatan religius seperti pada saat waktu Dhuha mereka akan segera mengambil air wudhu dan melaksanakannya tanpa disuruh lagi, ketika waktu Zhuhur mereka semua berwudu dengan tertib dan memasuki mushala tanpa ribut atau gaduh.

2. Saran

Penelitian ini perlu dilakukan penelitian lebih lanjut yang mampu mengungkapkan lebih spesifik dan mendalam tentang model pendidikan karakter yang diterapkan di Sekolah Dasar berbasis pondok-pondok pesantren baik itu salaf, maupun modern dan mengkombinasikannya agar memberikan kontribusi positif bagi penyelenggara pendidikan lainnya. 
Miftahul Jannah: Pendidikan Karakter pada Sekolah Dasar di Pondok Pesantren Dalam Pembentukan Kedisiplinan, Tanggung Jawab, dan Kemandirian Siswa

\section{Daftar Pustaka}

Basrowi dan Suwandi. Memahami Penelitian Kualitatif. Jakarta: Rineka Cipta, 2008.

Gulo, W. Strategi Belajar Mengajar. Jakarta: PT Raja Grafindo, 2005.

Hurlock, Elizabeth B. Perkembangan Anak, Diterjemahkan Oleh Med. Meitasari Tjandrasa. Jakarta: Penerbit Erlangga, T. Th.

Indonesia, Republik. Undang-Undang SISDIKNAS. Bandung: Fokusmedia, 2010.

J. Moleong, Lexi. Metode Penelitian Kualitatif. Bandung: PT. Remaja Rosdakarya, 2006.

Koesoema, Deni. Pendidikan Karakter Strategi Mendidik Anak di Zaman Global. Jakarta: Grasindo, 2010.

Malik. Oemar. Psikologi Belajar Mengajar. Bandung: Sinar Baru Algensindo, 2012.

Muchlish, Masnur. Pendidikan Karakter Menjawab Tantangan Krisis Multidemensional. Jakarta: Bumi Aksara. 2011.

Mufarokah, Anissatul. Strategi dan Model-Model Pembinaan. STAIN Tulungagung: Press, 2008.

Muhaimin. Paradigma Pendidikan Islam: Upaya Mengefektifkan Pendidikan Agama Islam di Sekolah. Bandung: PT Remaja Rosdakarya, 2008.

Muhammad Johan. Pendidikan karakter di Pondok Pesantren Sumenap. Tesis. UIN Maulana Malik Ibrahim. 2014.

Mulyani. Konsep Penanaman Disiplin pada Anak dalam Keluarga menurut Abdullah Nashih Ulwan. Tesis. UIN Sunan Kalijaga. 2008.

Mulyasa, E. Manajemen Pendidikan Karakter. Jakarta: PT Bumi Aksara, 2011.

Muhaimin. Paradigma Pendidikan Islam: Upaya Mengefektifkan Pendidikan Agama Islam di Sekolah. Bandung: PT Remaja Rosdakarya, 2008.

Samani, Muchlas Hariyanto. Konsep dan Model Pendidikan Karakter. Bandung: PT Remaja Rosdakarya, 2011.

Setiawan, Agus. Prinsip Pendidikan Karakter dalam Islam (Studi Komparasi Pemikiran al-Ghazali dan Burhanuddin al-Zarnuji), Dinamika Ilmu, 14 (1), 2014.

Suyanto. Pendidikan Karakter; Teori dan Aplikasi. Jakarta: Aneka Cipta.

Jurnal Ilmiah AL-MADRASAH, Vol. 2, No. 2, Januari-Juni 2018 
Miftahul Jannah: Pendidikan Karakter pada Sekolah Dasar di Pondok Pesantren Dalam Pembentukan Kedisiplinan, Tanggung Jawab, dan Kemandirian Siswa

Tabrani, A. Dkk. Upaya Meningkatkan Budaya Kinerja Guru Sekolah Dasar (T.Tp. Inti Media Cipta Nusantara, 2001.

Tim Penyusun Kamus Pusat Pembinaan dan Pengembangan Bahasa Dep. Pendidikan Kebudayaan. Kamus Besar Bahasa Indonesia. Jakarta: Balai Pustaka, 1998.

Tu'u, Tulus. Peran Disiplin Pada Perilaku dan Prestasi Siswa. Jakarta: Gramedia Widia Sarana Indonesia, 2004.

Wibowo, Agus. Pendidikan Karakter, Strategi Membangun Karakter Bangsa. Yogyakarta: Pustaka Pelajar, 2012.

Wirawan, Model Pendidikan Karakter melalui kegiatan Belajar Mengajar di SMA Islam Terpadu Martapura. Tesis. UIN Antasari Banjarmasin. 2013.

Yasin, A. Fatah. Dimensi-Dimensi Pendidikan Islam. Yogyakarta: Sukses Offset, 2008.

Yaqin, Husnul. Sistem Pendidikan Pesantren di Kalimantan Selatan, Banjarmasin: Antasari Press, 2010.

Jurnal Ilmiah AL-MADRASAH, Vol. 2, No. 2, Januari-Juni 2018 